\title{
Profile of women with lymphedema affer breast cancer treatment
}

\author{
Perfil de mulheres com linfedema no pós-tratamento de câncer de mama \\ Perfil de mujeres con linfedema en post tratamiento de cáncer de mama
}

Thais de Oliveira Gozzo'
Gabriela Aguado
Aniele Tomadon
A

Marislei Sanches Panobianco ${ }^{1}$ (D) Maria Antonieta Spinoso Prado ${ }^{1}$ (1)

1. Universidade de São Paulo, Escola de Enfermagem de Ribeirão Preto. Ribeirão Preto, SP, Brasil.

2. Programa de Residência Multiprofissional em Atenção ao Câncer, Hospital de Câncer de Barretos. Barretos-SP, Brasil.
Corresponding author:

Thais de Oliveira Gozzo

E-mail: thaisog@eerp.usp.br

Submitted on $03 / 29 / 2019$

Accepted on 07/26/2019

DOI: 10.1590/2177-9465-EAN-2019-0090

\begin{abstract}
Objective: To identify the profile of women with lymphedema after breast cancer treatment. Methods: This is a descriptive, retrospective and quantitative study with data from medical records of women with lymphedema who began treatment between 2010 and 2015 in a rehabilitation center. An instrument was used for data collection to characterize the participants and analysis was performed by means of descriptive statistics, the Chi-Square test and Fisher's exact test. Results: 235 women with a mean age of 56.8 years were included, with an association between lymphedema and age $(p=0.016)$. It was observed that $76.6 \%$ of the sample had some comorbidity associated with breast cancer, especially hypertension (48.1\%). They underwent radical surgery $(60 \%)$, axillary lymphadenectomy $(77.9 \%)$, sentinel lymph node biopsy (16.6\%) and radiotherapy $(74 \%)$. Treatments carried out for lymphedema were decongestant therapy and complementary treatments with $95.7 \%$ of adherence of women to therapies. Conclusion and implications for practice: Women with lymphedema presented risk factors such as radical surgery, axillary lymphadenectomy and radiotherapy, and good adherence to the required treatments of lymphedema. Knowing the profile of this population is crucial to the treatment choice.
\end{abstract}

Keywords: Lymphedema; Breast cancer; Women's health.

\section{Resumo}

Objetivo: Identificar o perfil de mulheres com linfedema após tratamento do câncer de mama. Métodos: Estudo descritivo, retrospectivo e quantitativo com dados de prontuários de mulheres com linfedema que iniciaram atendimento entre 2010 e 2015 em um núcleo de reabilitação. Para coleta de dados foi utilizado instrumento para a caracterização das participantes e análise por meio de estatística descritiva e teste de Qui-Quadrado e Fisher. Resultados: Foram incluídas 235 mulheres com média de idade de 56,8 anos havendo associação entre linfedema e idade $(p=0,016)$. Observou-se que $76,6 \%$ da amostra apresentaram alguma comorbidade associada ao câncer de mama com destaque para hipertensão (48,1\%). Foram submetidas a cirurgia radical $(60 \%)$, linfadenectomia axilar $(77,9 \%)$, biopsia do linfonodo sentinela $(16,6 \%)$ e radioterapia $(74 \%)$. Os tratamentos para cuidados com o linfedema foram terapia descongestiva e tratamentos complementares com adesão de $95,7 \%$ das mulheres às terapias. Conclusão e Implicações para a prática: As mulheres com linfedema apresentaram fatores de risco como cirurgia radical, linfadenectomia axilar e radioterapia, e boa adesão aos tratamentos necessários para controle do linfedema. Conhecer o perfil desta população é primordial para eleição de tratamentos.

Palavras-chave: Linfedema; Neoplasias da mama; Saúde da mulher; Enfermagem oncológica.

\section{RESUMEN}

Objetivo: Identificar el perfil de mujeres con linfedema después del tratamiento del cáncer de mama. Métodos: Estudio descriptivo, retrospectivo y cuantitativo con datos de fichas médicas de mujeres con linfedema que fueron atendidas entre 2010 y 2015 en un núcleo de rehabilitación. Para la recogida de datos fue utilizado instrumento para caracterizar a las participantes y el análisis fue hecho por medio de estadística descriptiva con las pruebas de Chi-Cuadrado y Fisher. Resultados: Fueron incluidas 235 mujeres con edad media de 56,8 años, habiéndose encontrado asociación entre linfedema y edad ( $p=0,016)$. Se observó que 76,6\% de la muestra presentó alguna comorbilidad asociada al cáncer de mama con destaque para la hipertensión (48,1\%). Fueron sometidas a cirugía radical $(60 \%)$, a linfadenectomía axilar $(77,9 \%)$, a biopsia del linfonodo centinela $(16,6 \%$ ) y a radioterapia ( $74 \%)$. Los tratamientos para cuidados con el linfedema fueron la terapia descongestiva y tratamientos complementarios con adhesión de 95,7\% de las mujeres a las terapias. Conclusión e Implicaciones para la práctica: Las mujeres con linfedema presentaron factores de riesgo como cirugía radical, linfadenectomía axilar y radioterapia; se encontró buena adhesión a los tratamientos necesarios para el control del linfedema. Conocer el perfil de esta población es primordial para seleccionar los tratamientos.

Palabras clave: Linfedema; Neoplasias de mama; Salud de la mujer; Enfermería oncológica. 


\section{INTRODUCTION}

As cancer treatments progress, there is increased concern with the quality of life of patients, and one of the greatest complications of breast cancer is lymphedema. ${ }^{1.2}$

Breast cancer-related lymphedema is defined as a chronic and progressive disease, as shown in a prospective cohort study carried out with 964 women with breast cancer. The lymphedema cumulative incidence observed was $13.5 \%$ after two years of follow-up, $30.2 \%$ after five years, reaching $41.1 \%$ after 10 years. ${ }^{3}$

The cause of lymphedema is the abnormal lymph build up in the interstitial space. This build up is the result of a lymph system failure in the homolateral limb, generally triggered by surgical procedures and/or radiotherapy in the axillary region. ${ }^{4-6}$

The diagnosis of lymphedema can be made by means of subjective criteria with the symptoms reported by the patient, such as a feeling of heaviness, swelling, and reduced limb mobility, or by means of objective criteria such as circumference, volumetry, ultrasonography, and spectroscopic bioimpedance. ${ }^{7,8}$

Most women with breast cancer-related lymphedema have altered mobility in the affected limb, thus making daily activities and routine more difficult. In addition to the loss of physical functions, lymphedema leads to fear of worsening of the condition and changes in the body image perception, resulting in a downturn of emotional and psychosocial aspects, such as low self-esteem, anxiety and depression, all of which affect interpersonal relationships. ${ }^{\text {8-10 }}$

In this context, it is essential to identify common characteristics in women who have breast cancer-related lymphedema to improve prevention and handling of this comorbidity by health professionals, aiming at a better quality of life for this population.

Therefore, the objective of this study was to outline the profile of women with lymphedema after breast cancer treatment.

\section{MATERIAL AND METHODS}

This is a quantitative, cross-sectional, and retrospective study. Data were collected from medical records of women with breast cancer who were cared for in a health care center for women with breast cancer located in the state of São Paulo. The studied sample consisted of records of women who underwent treatment between January 2010 and December 2015 and who had a follow-up until August 2017.

The inclusion criteria were records of women with breast cancer cared for in the aforementioned rehabilitation service and who had lymphedema during the study follow-up period. In order to identify the lymphedema, the circumference of upper limbs was measured by means of an 8-meter measuring tape and differences of over 2 centimeters $(\mathrm{cm})$ were defined as lymphedema. ${ }^{8}$ The exclusion criterion was medical records that did not contain the necessary data for the study.

An instrument was used to extract data with the following variables: social and demographic profiles, related diseases, treatment performed for cancer and for limbs with lymphedema, and weight and height reported at admission which allowed for BMI (body mass index) calculation, which is the body weight (kilograms- $\mathrm{kg}$ ) divided by the square of the body height (meters-m), $\left(\mathrm{kg} / \mathrm{m}^{2}\right)$.

The BMI scale adopted was $<18.5$ for underweight, between 18.5-24.9 for normal weight, between 25-29.9 for overweight, between 30-34.9 for obese level 1, between 35-39.9 obese level 2 and $\geq 40$ obese level $3 .{ }^{11}$

Data were entered twice in an Excel spreadsheet and were analyzed by means of descriptive statistics of variables and by association tests with the chi-square and Fisher's exact tests, considering a significance level of 0.05. Data were processed in IBM SPSS Statistics version 25 and $R$ i386 version 3.4.0.

This study was approved by the institution's research ethics committee, meeting the requirements and guidelines of human research, found in Resolution CNS 466/2012 (Protocol CAAE: 60391916.4.0000.5393).

\section{RESULTS}

In the period of study, 423 women were enrolled, 235 of which were included, indicating that $55.5 \%$ of them had lymphedema. Of the included medical records, women were aged between 26 to 88 years, with an average age of 56.8 years $(S D=12.3$ years). $97.9 \%$ came from the state of São Paulo, $53.6 \%$ were in a steady relationship and $49.4 \%$ of women had up to 4 years of education. Women who did unpaid work accounted for $38.8 \%$ (Table 1).

Table 1. Distribution of women with lymphedema by age, origin, marital status, education, occupation, and comorbidities. Ribeirão Preto, 2017. ( $\mathrm{N}=235)$.

\begin{tabular}{lcc}
\hline Variable & $\mathbf{N}$ & $\%$ \\
\hline Age & & \\
$\leq 39$ & 26 & 11 \\
$40 \mid-49$ & 56 & 23.8 \\
$50 \mid-59$ & 82 & 34.9 \\
$60 \mid-69$ & 40 & 17 \\
$\geq 70$ & 31 & 13.3 \\
Origin & & \\
Cities from the State of São Paulo & 230 & 97.9 \\
Cities from other Brazilian States & 4 & 2.1 \\
Marital status & & \\
With partner & 126 & 53.6 \\
No partner & 108 & 46 \\
Not informed & 1 & 0.4 \\
Education (in years) & & \\
Illiterate & 9 & 3.8 \\
$\leq 4$ & 116 & 49.4 \\
5 |- 8 & 19 & 8.1 \\
9 |- 12 & 58 & 24.7 \\
$\geq 13$ & 33 & 14 \\
\hline & & Continue... \\
\hline & &
\end{tabular}


Continuation...

\begin{tabular}{lcc}
\hline Variable & N & \% \\
\hline Occupation & & \\
Unpaid work & 77 & 32.8 \\
Paid work & 48 & 20.4 \\
Retired & 30 & 12.8 \\
Others & 69 & 29.3 \\
Not informed & 11 & 4.7 \\
Comorbidities & & \\
Yes & 180 & 76.6 \\
No & 55 & 23.4 \\
Which comorbidities* & & \\
Systemic arterial hypertension & 113 & 48.1 \\
Diabetes mellitus & 40 & 17 \\
Obesity & 103 & 43.9 \\
BMI & & \\
< 18.5 & 1 & 0.4 \\
18.5 | - 24.9 & 41 & 17.4 \\
25 I - 29.9 & 81 & 34.5 \\
30 | - 34.9 & 58 & 24.7 \\
35 | - 39.9 & 21 & 9 \\
$\geq 40$ & 24 & 10.2 \\
Not informed & 9.8 \\
\hline
\end{tabular}

* Each woman could have more than one comorbidity.

It was observed that $76.6 \%$ of the sample had some comorbidity associated with breast cancer. It was also found that $43.9 \%$ of women were obese and $48.1 \%$ had systemic arterial hypertension (Table 1).

It was found that $68.1 \%$ of the 235 women had a difference equal to or greater than $2 \mathrm{~cm}$ in the upper limb circumference at the time of admission, that is, they sought care when the lymphedema was already established.

Among the analyzed women, $51.6 \%$ had breast cancer on the right side, $40.8 \%$ on the left side and for $7.6 \%$ of them, the cancer was bilateral. Mastectomy was the most performed surgical treatment, to which $60 \%$ of women were submitted, and with regard to the lymphatic system, $77.9 \%$ of women were submitted to axillary lymphadenectomy (Table 2).

In addition, women were submitted to other treatments such as neoadjuvant chemotherapy (48.5\%) and adjuvant chemotherapy (43\%), radiotherapy (74\%) and hormone therapy (57\%) as shown in Table 2.

Association tests were performed considering the risk factors ${ }^{2}$ for lymphedema development, as presented in Table 3. There is a significant association between the development of the lymphedema and women's age at the time of diagnosis $(p=0.016)$. Other variables such as hypertension, axillary lymphadenectomy, radiotherapy, and BMI did not have a significant association $(p>0.05)$.
Table 2. Distribution of women with lymphedema according to treatment performed. Ribeirão Preto, 2017. $(\mathrm{N}=235)$.

\begin{tabular}{|c|c|c|}
\hline Variable & $\mathbf{N}$ & $\%$ \\
\hline \multicolumn{3}{|l|}{ Surgery* } \\
\hline Radical surgery & 141 & 60 \\
\hline Conservative surgery & 80 & 34 \\
\hline Did not undergo surgery & 2 & 0.9 \\
\hline Not informed & 12 & 5.1 \\
\hline \multicolumn{3}{|l|}{ Sentinel lymph node } \\
\hline Yes & 39 & 16.6 \\
\hline No & 131 & 55.7 \\
\hline Not informed & 65 & 27.7 \\
\hline \multicolumn{3}{|c|}{ Axillary lymphadenectomy } \\
\hline Yes & 183 & 77.9 \\
\hline No & 12 & 5.1 \\
\hline Not informed & 40 & 17 \\
\hline \multicolumn{3}{|c|}{ Neoadjuvant Chemotherapy } \\
\hline Yes & 114 & 48.5 \\
\hline No & 120 & 51.1 \\
\hline Not informed & 1 & 0.4 \\
\hline \multicolumn{3}{|l|}{ Adjuvant Chemotherapy } \\
\hline Yes & 101 & 43 \\
\hline No & 124 & 52.8 \\
\hline Not informed & 10 & 4.3 \\
\hline \multicolumn{3}{|l|}{ Radiotherapy } \\
\hline Yes & 174 & 74 \\
\hline No & 46 & 19.6 \\
\hline Not informed & 15 & 6.4 \\
\hline \multicolumn{3}{|l|}{ Hormone Therapy } \\
\hline Yes & 134 & 57 \\
\hline No & 83 & 35.3 \\
\hline Not informed & 18 & 7.7 \\
\hline
\end{tabular}

*Surgery: Radical mastectomy: Conservative - lumpectomy, quadrantectomy, and nodulectomy.

After the identification of the lymphedema, $96.1 \%$ of women underwent the suggested treatments, which consisted of 2 or 3 weekly appointments. Compressive bandaging of the limb was performed in $35.3 \%$ of women, $23.8 \%$ of them performed manual lymphatic drainage, $95.7 \%$ did myolymphokinetic exercises, $29.8 \%$ used an armband and $17.4 \%$ were submitted to highvoltage electrical stimulation (HVPC). The same women may have followed more than one treatment according to their needs. 
Table 3. Association between lymphedema and risk factors for its development. Ribeirão Preto, 2017. ( $N=235)$

\begin{tabular}{|c|c|c|c|c|c|c|c|}
\hline & & & \multicolumn{4}{|c|}{ Circumference of upper limbs } & \multirow{2}{*}{$p$-value* } \\
\hline & & & $<3 \mathrm{~cm}$ & $3-5 \mathrm{~cm}$ & $>5 \mathrm{~cm}$ & Total & \\
\hline \multirow{10}{*}{ Age } & \multirow{2}{*}{$26.5-39.9$} & $\mathrm{~N}$ & 8 & 8 & 3 & 19 & \multirow{10}{*}{0.016} \\
\hline & & $\%$ & 42.1 & 42.1 & 15.8 & 100 & \\
\hline & \multirow{2}{*}{$40.0-49.9$} & $\mathrm{~N}$ & 35 & 14 & 1 & 50 & \\
\hline & & $\%$ & 70 & 28 & 2 & 100 & \\
\hline & \multirow{2}{*}{$50.0-59.9$} & $\mathrm{~N}$ & 59 & 14 & 10 & 83 & \\
\hline & & $\%$ & 71.1 & 16.9 & 12 & 100 & \\
\hline & \multirow{2}{*}{$60.0-69.9$} & $\mathrm{~N}$ & 29 & 10 & 5 & 44 & \\
\hline & & $\%$ & 65.9 & 22.7 & 11.4 & 100 & \\
\hline & \multirow{2}{*}{70 ou mais } & $\mathrm{N}$ & 19 & 11 & 9 & 39 & \\
\hline & & $\%$ & 48.7 & 28.2 & 23.1 & 100 & \\
\hline \multirow{8}{*}{ BMI } & \multirow{2}{*}{$\begin{array}{l}\text { Low weight } \\
\quad(<18.5)\end{array}$} & $\mathrm{N}$ & 1 & 0 & 0 & 1 & \multirow{8}{*}{0.93} \\
\hline & & $\%$ & 100 & 0 & 0 & 100 & \\
\hline & Eutrophic & $\mathrm{N}$ & 26 & 9 & 6 & 41 & \\
\hline & $(18.5-24.9)$ & $\%$ & 63.4 & 22 & 14.6 & 100 & \\
\hline & Overweight & $\mathrm{N}$ & 54 & 19 & 8 & 81 & \\
\hline & $(25.0-29.9)$ & $\%$ & 66.7 & 23.5 & 9.9 & 100 & \\
\hline & \multirow{2}{*}{ Obesity } & $\mathrm{N}$ & 64 & 26 & 13 & 103 & \\
\hline & & $\%$ & 62.1 & 25.2 & 12.6 & 100 & \\
\hline \multirow{4}{*}{ Radiotherapy } & \multirow{2}{*}{ Yes } & $N$ & 105 & 44 & 25 & 174 & \multirow{4}{*}{0.059} \\
\hline & & $\%$ & 60.3 & 25.3 & 14.4 & 100 & \\
\hline & \multirow{2}{*}{ No } & $\mathrm{N}$ & 36 & 8 & 2 & 46 & \\
\hline & & $\%$ & 78.3 & 17.4 & 4.3 & 100 & \\
\hline \multirow{4}{*}{$\begin{array}{l}\text { Axillary } \\
\text { lymphadenectomyr }\end{array}$} & \multirow{2}{*}{ Yes } & $\mathrm{N}$ & 116 & 47 & 20 & 183 & \multirow{4}{*}{0.314} \\
\hline & & $\%$ & 63.4 & 25.7 & 10.9 & 100 & \\
\hline & \multirow{2}{*}{ No } & $\mathrm{N}$ & 9 & 1 & 2 & 12 & \\
\hline & & $\%$ & 75 & 8.3 & 16.7 & 100 & \\
\hline \multirow{4}{*}{ Hypertension } & \multirow{2}{*}{ Yes } & $\mathrm{N}$ & 74 & 22 & 17 & 113 & \multirow{4}{*}{0.132} \\
\hline & & $\%$ & 65.5 & 19.5 & 15 & 100 & \\
\hline & \multirow{2}{*}{ No } & $\mathrm{N}$ & 74 & 35 & 11 & 120 & \\
\hline & & $\%$ & 61.7 & 29.2 & 9.2 & 100 & \\
\hline
\end{tabular}

* Fischer's exact test

\section{DISCUSSION}

Lymphedema had a higher incidence in women aged between 50-59 years with a positive association for age ( $p$ $=0.016$ ). This is observed in the literature and is justified by the fact that the underlying disease is more frequent in older women due to the amount of exposure and biological changes throughout life..$^{12,13}$

A BMI between overweight and obesity $(\geq 25 \mathrm{~kg} / \mathrm{m})$ was observed in $78.4 \%$ of women with lymphedema, which is line with the literature that points out to overweight or obesity as a risk factor for lymphedema. ${ }^{1,6,14} \mathrm{An}$ observational study carried out with 100 women investigated the prevalence of lymphedema in overweight or obese women who underwent mastectomy and it found that overweight women are twice as likely to have lymphedema, and for those who have level 1 obesity, the risk of developing this comorbidity is around six times higher. ${ }^{6}$ Another prospective study with 787 women with breast cancer assessed the impact of pre-operative $\mathrm{BMl}$ and the change in weight after treatment on the incidence of lymphedema and it concluded 
that a BMI over 30 in the pre-operative period is an independent risk factor for lymphedema and a weight fluctuation of $4.5 \mathrm{~kg}$ per month (gain or loss) during the post-operative period results in a higher risk for lymphedema. ${ }^{15}$

Systemic arterial hypertension is a very much prevalent condition, found in $48.1 \%$ of women of this study. These data are confirmed by a systematic review of the literature, which found that women with breast cancer and arterial hypertension have an increased risk of 1.83 times for the development of lymphedema compared to those who do not have these conditions (OR 1.83). ${ }^{16}$

Factors related to surgery, such as its radical nature and the performance of axillary lymphadenectomy, are mentioned in the literature as a risk factor for lymphedema development. The dissection of the axillary lymph node has been pointed as an important risk factor for lymphedema development after breast cancer treatment, with a risk that is 2.72 times higher compared to the group that did not undergo this procedure. ${ }^{16}$ The results of our study confirm these findings since $77.9 \%$ of the studied women underwent axillary lymphadenectomy.

Axillary radiotherapy for breast cancer treatment is defined in the literature as a risk factor for lymphedema. A study carried out with women diagnosed with breast cancer found that $65.2 \%$ of the sample was treated with radiotherapy at some stage, whereas in our study sample $74 \%$ of women with lymphedema underwent radiotherapy. ${ }^{3,16,17}$

The conservative treatment of lymphedema tries to reduce edema and increase mobility of the lymph. Among the existing techniques, there is the complex decongestive therapy (CDT), recognized by the International Society of Lymphology, which is divided into two stages: the first stage aims to reduce the size of the affected limb by means of skin care, manual lymphatic drainage, compressive bandaging and myolymphokinetic exercises with the upper limbs; the second stage aims to control the lymphedema with the use of compression sleeves, in addition to skin care, exercises and lymphatic self-massage. . $^{18-20}$

Practicing different physical exercises such as aerobics, endurance exercises, stretching, yoga, qi gong, and Pilates have proved to be safe and efficient in the management of symptoms in patients with lymphedema or with a risk of developing it, according to a systematic review of 26 articles carried out recently. ${ }^{21}$ However, the therapeutic myolymphokinetic exercises have greater visibility since they are found in CDT and were performed in this study in compliance with a protocol of gradual warm up of muscle chains, exercises for increased joint range and muscle stretching and relaxation. ${ }^{22}$

According to a systematic review about manual lymphatic drainage for lymphedema after breast cancer, the technique is considered to be safe and well tolerated, but there is a lack of studies that used only drainage for group comparison. ${ }^{23}$ With regard to the Brazilian population, manual lymphatic drainage was studied in a reference service and it was also associated with other techniques such as skin care, bandaging and corrective exercises in treatments with an average duration of 24 days. As a result, a significant decrease in the affected arm size was observed $(p<0.001) .{ }^{24}$
Compressive bandaging and armbands, used by $35.3 \%$ and $29.8 \%$ of women respectively, consist of applying pressure. A randomized study with 95 women compared the efficiency of treatments that used armbands in the control group to daily manual lymphatic drainage and compressive bandage followed by the use of armbands in the experimental group. The authors observed that both treatments saw a decrease in limb size; however, when this comparison was made between groups, neither treatments had a significant difference. ${ }^{25}$ Nevertheless, the additional benefit of those instruments is that both provide a certain degree of protection to the limb, avoiding accidental skin injuries such as burns, abrasions, tears or insect bites. ${ }^{26}$

Another technique used in the service was HVPC, with the same parameters used by a study which found that the application of this technology in women with lymphedema along with exercises and guidance on care of the affected limb obtained a significant decrease of $13.8 \%(p=0.0089)$ in limb size, and $14.1 \%$ $(p=0.0067)$ in the increased volume percentage in comparison with the contralateral limb. ${ }^{27}$ Despite not being frequently used, HVPC helps to reduce the permeability of microcirculation, by reducing pore size of capillaries and restraining the displacement of proteins to the interstitial space when it is associated with the compression made by the striated skeletal muscle and the smooth muscle found in lymphatic vessels. ${ }^{27}$

In addition to the impairment of the affected limb, there is loss in emotional, cognitive and social functions which can be persistent over the long term in women with breast cancer ${ }^{10}$, and the referred service provides emotional support to women. It also helps women's social reintegration to society by means of contact with other women who are in a similar situation and with whom they can share experiences and have mutual social and emotional support.

As limitations of this study, we can mention secondary data, since registered information very often did not comply with the objectives of the study and participants had to be excluded, thus compromising the sample.

\section{CONCLUSIONS AND IMPLICATIONS FOR PRACTICE}

It was possible to observe that women who developed lymphedema had risk factors evidenced by the literature such as the presence of comorbidities like obesity and arterial hypertension, in addition to the performance of radical surgeries, axillary lymphadenectomy, and radiotherapy. It was also observed that treatments available in the service include CDT and additional techniques and that there was good adherence to myolymphokinetic exercises.

Information collected in this study is important for the multiprofessional team as it can implement new actions or improve the existing ones, such as educational activities for prevention and management of lymphedema. In addition to including other aspects, such as the control of blood pressure and obesity. Health services must be aware of the profile of women who are being cared for so they can adapt to their reality and ensure the effectiveness of treatment. 


\section{FINANCIAL SUPPORT}

Brazilian Federal Agency for Support and Evaluation of Graduate Education (CAPES, as per its acronym in Portuguese), with funding code 1750777, PhD scholarship granted to Aniele Tomadon.

\section{REFERENCES}

1. Ugur S, Arıcı C, Yaprak M, Mescı A, Arıcı GA, Dolay K, et al. Risk factors of breast cancer-related lymphedema. Lymphat Res Biol [Internet]. 2013 Jun;11(2):72-5. Available from: https://www.liebertpub.com/doi/10.1089/ Irb.2013.0004. DOI: 10.1089/Irb.2013.0004

2. Kim M, Shin KH, Jung SY, Lee S, Kang HS, Lee ES, et al. Identification of prognostic risk factors for transient and persistent lymphedema after multimodal treatment for breast cancer. Cancer Res Treat [Internet]. 2016 Oct;48(4):1330-7. Available from: https://www.ncbi.nlm.nih. gov/pmc/articles/PMC5080824/. DOI: 10.4143/crt.2015.463

3. Ribeiro Pereira ACP, Koifman RJ, Bergmann A. Incidence and risk factors of lymphedema after breast cancer treatment: 10 years of follow-up. Breast [Internet]. 2017 Dec;36:67-73. Available from: https://www.ncbi. nlm.nih.gov/pubmed/28992556. DOI: 10.1016/j.breast.2017.09.006

4. Hespe GE, Nitti MD, Mehrara BJ. Pathophysiology of lymphedema. In: Greene AK, Slavin SA, Brorson H, eds. Lymphedema presentation, diagnosis, and treatment. Cham: Springer; 2015.

5. Chowdhry M, Rozen WM, Griffiths M. Lymphatic mapping and preoperative imaging in the management of post-mastectomy lymphoedema. Gland Surg [Internet]. 2016 Apr;5(2):187-96. Available from: http://gs.amegroups.com/article/view/9089/9897. DOI: 10.3978/j. issn.2227-684X.2015.11.06

6. Paiva CB, Dutra CMS. Prevalência de linfedema após tratamento de câncer de mama em pacientes com sobrepeso. Fisioter Pesqui [Internet]. 2016;23(3):263-7. Available from: http://www.scielo.br/ scielo.php?script=sci_arttext\&pid=S1809-29502016000300263. DOI: 10.1590/1809-2950/15214123032016

7. Vieira RAC, Silva FCB, Biller G, Silva JJ, Paiva CE, Sarri AJ. Instrumentos de avaliação quantitativa e qualitativa das sequelas relacionadas ao tratamento do câncer de mama. Rev Bras Mastologia [Internet]. 2016;26(3):126-32. Available from: http://www.mastology.org/wpcontent/uploads/2016/06/MAS_v26n3_126-132.pdf . DOI: 10.5327/ Z201600030008RBM

8. Park JH, Lee SK, Lee JE, Kim SW, Nam SJ, Kim JY, et al. Breast Cancer Epidemiology of the Working-Age Female Population Reveals Significant Implications for the South Korean Economy. J Breast Cancer [Internet]. 2018 Mar;21(1):91-5. Available from: https://www.ncbi.nlm.nih.gov/pubmed/29628989. DOI: 10.4048/ jbc.2018.21.1.91

9. Barbosa PA, Cesca RG, Pacífico TED, Leite ICG. Quality of life in women with breast cancer, after surgical intervention, in a city in the zona da mata region in Minas Gerais, Brazil. Rev Bras Saude Mater Infant [Internet]. 2017;17(2):385-99. Available from: http://www.scielo. br/scielo.php?script=sci_arttext\&pid=S1519-38292017000200385. DOI: 10.1590/1806-93042017000200010

10. DiSipio T, Rye S, Newman B, Hayes S. Incidence of unilateral arm lymphoedema after breast cancer: a systematic review and metaanalysis. Lancet Oncol [Internet]. 2013 May;14(6):500-15. Available from: https://www.ncbi.nlm.nih.gov/pubmed/23540561. DOI: 10.1016/ S1470-2045(13)70076-7

11. World Health Organization (WHO). Obesity: preventing and managing the global epidemic. Report of a World Health Organization Consultation [Internet]. Geneva: World Health Organization; 2000. 256 p. Available from: https://www.who.int/nutrition/publications/obesity/WHO_ TRS_894/en/
12. Uclés Villalobos V, Mata Jiménez L, Matamoros Sánchez A Descripción de la población de personas con cáncer de mama referida al Programa de Rehabilitación en Cáncer y Cuidados Paliativos del Servicio de Fisiatría del Hospital Dr. Rafael Ángel Calderón Guardia, 01 de junio del 2012 al 31 de mayo del 2013. Rev Costarric Salud Pública [Internet]. 2017 Jan/Jun;26(1):30-44. Available from: https://www.scielo.sa.cr/scielo.php?script=sci_arttex t\&pid=S1409-14292017000100030

13. World Health Organization (WHO). Breast cancer: prevention and control [Internet]. Available from: http://www.who.int/cancer/detection/ breastcancer/en/

14. Fu MR, Axelrod D, Guth AA, Fletcher J, Qiu JM, Scagliola J, et al. Patterns of Obesity and Lymph Fluid Level during the First Year of Breast Cancer Treatment: A Prospective Study. J Pers Med [Internet] 2015 Sep;5(3):326-40. Available from: https://www.ncbi.nlm.nih.gov/ pubmed/26404383. DOI: 10.3390/jpm5030326

15. Jammallo LS, Miller CL, Singer M, Horick NK, Skolny MN, Specht $\mathrm{MC}$, et al. Impact of body mass index and weight fluctuation on lymphedema risk in patients treated for breast. Breast Cancer Res Treat [Internet]. $2013 \mathrm{Nov} ; 142(1): 59-67$. Available from: https://link. springer.com/article/10.1007/s10549-013-2715-7. DOI: 10.1007/ s10549-013-2715-7

16. Das N, Baumgartner RN, Riley EC, Pinkston CM, Yang D, Baumgartner KB. Treatment-related risk factors for arm lymphedema among long-term breast cancer survivors. J Cancer Surviv [Internet]. 2015 Sep;9(3):422 30. Available from: https://link.springer.com/article/10.1007/s11764014-0416-9. DOI: 10.1007/s11764-014-0416-9

17. Ahmed RL, Schmitz KH, Prizment AE, Folsom AR. Risk factors for lymphedema in breast cancer survivors, the lowa Women's Health Study. Breast Cancer Res Treat [Internet]. 2011 Dec;130(3):981-91. Available from: https://link.springer.com/article/10.1007/s10549-011-1667-z. DOI: 10.1007/s10549-011-1667-z

18. Tambour M, Tange B, Christensen R, Gram B. Effect of physical therapy on breast cancer related lymphedema: protocol for a multicenter, randomized, single-blind, equivalence trial. BMC Cancer [Internet] 2014 Apr;14:239. Available from: https://www.ncbi.nlm.nih.gov/ pubmed/24708851. DOI: 10.1186/1471-2407-14-239

19. Fabro EAN, Costa RM, Oliveira JF, Lou MBA, Torres DM, Ferreira FO, et al. Atenção fisioterapêutica no controle do linfedema secundário ao tratamento do câncer de mama: rotina do Hospital do Câncer III/Instituto Nacional de Câncer. Rev Bras Mastologia [Internet]. 2016;26(1):4-8. Available from: http://www.mastology.org/ wp-content/uploads/2016/03/MAS-v26n1_4-8.pdf. DOI: 10.5327/ Z201600010002RBM

20. Executive Committee. The Diagnosis and Treatment of Periphera Lymphedema: 2016 Consensus Document of the International Society of Lymphology. Lymphology [Internet].2016 Dec;49(4):170-84. Available from: https://www.ncbi.nlm.nih.gov/pubmed/?term=The+Diagnosis+an $\mathrm{d}+$ Treatment+of+Peripheral+Lymphedema\%3A+2016+Consensus+D ocument+of+the+International+Society+of+Lymphology

21. Panchik D, Masco S, Zinnikas P, Hillriegel B, Lauder T, Suttmann E, et al. Effect of Exercise on Breast Cancer-Related Lymphedema: What the Lymphatic Surgeon Needs to Know. J Reconstr Microsurg [Internet]. 2019 Jan;35(1):37-45. Available from: https://www.ncbi.nlm.nih.gov/ pubmed/29935493. DOI: 10.1055/s-0038-1660832

22. Mundim e Barros V, Panobianco MS, Almeida AM, Guirro ECO. Linfedema pós-mastectomia: um protocolo de tratamento. Fisioter Pesqui [Internet] 2013 Apr/Jun;20(2):178-83. Available from: http://www.scielo.br/ scielo.php?script=sci_arttext\&pid=S1809-29502013000200013. DOI: 10.1590/S1809-29502013000200013

23. Ezzo J, Manheimer E, McNeely ML, Howell DM, Weiss R, Johansson $\mathrm{KI}$, et al. Manual lymphatic drainage for lymphedema following breast cancer treatment. Cochrane Database Syst Rev [Internet]. 2015 May;5:CD003475. Available from: https://www.cochranelibrary.com/ cdsr/doi/10.1002/14651858.CD003475.pub2/full 
24. Bergmann A, da Costa Leite Ferreira MG, de Aguiar SS, de Almeida Dias R, de Souza Abrahao K, Paltrinieri EM, et al. Physiotherapy in upper limb lymphedema after breast cancer treatment: a randomized study. Lymphology [Internet]. 2014 Jun;47(2):82-91. Available from: https:// www.ncbi.nlm.nih.gov/pubmed/25282874

25. Dayes IS, Whelan TJ, Julian JA, Parpia S, Pritchard KI, D'Souza DP, et al. Randomized trial of decongestive lymphatic therapy for the treatment of lymphedema in women with breast cancer. J Clin Oncol [Internet]. 2013 Oct;31(30):3758-63. Available from: https://ascopubs.org/doi/10.1200/ JCO.2012.45.7192. DOI: 10.1200/JCO.2012.45.7192
26. Luz ND, Lima ACG. Recursos fisioterapêuticos em linfedema pósmastectomia: uma revisão de literatura. Fisioter Mov [Internet]. 2011 Jan/Mar;24(1):191-200. Available from: http://www.scielo.br/scielo. php?script=sci_arttext\&pid=S0103-51502011000100022. DOI 10.1590/S0103-51502011000100022

27. Garcia LB, Guirro ECO. Efeitos da estimulação de alta voltagem no linfedema pós-mastectomia. Rev Bras Fisioter. 2005 May/ Aug;9(2):243-8. 